\title{
Investigation of the Crime of Embezzlement in Property
}

\author{
Oliestha Ageng Wicaksana ${ }^{*}$ and Umar Ma'ruf ${ }^{* *}$ \\ *) Student of Master of Law, Universitas Islam Sultan Agung Semarang and \\ Member of The Indonesian National Police, email: oliestha71@gmail.com \\ ${ }^{* *}$ Faculty of Law, Universitas Islam Sultan Agung
}

\begin{abstract}
The purpose of this research to find out and analyze the process of investigating criminal acts of embezzlement in positions in the Ciamis Police jurisdiction, obstacles in the process of investigating criminal acts of embezzlement in positions in the Ciamis Police jurisdiction, and analyzing solutions in overcoming obstacles in the process of investigating criminal acts of embezzlement in positions in the region the law of the Ciamis Police. This study uses an empirical juridical approach with descriptive analysis research specifications. The data used are primary data and secondary data obtained through interviews and literature study. The data analysis method used was qualitative analysis. Furthermore, based on the results of the research, it can be concluded: Investigations on suspects of embezzlement in positions in the Ciamis Police jurisdiction with Police Report case Number: LP / 74 / B / III / 2019 / JBR / SPKT Res Ciamis, March 30, 2019 on behalf of the reporter OHT Bin JA, namely as follows: Crime Scene Examination, Investigation, Preparation of Minutes, Examination of evidence: Search, confiscation, Expert statements, arrest or detention and examination of suspects, Resume and submission of files Obstacles: not everyone knows, hearing of a criminal act of embezzlement who wants to report to the legal apparatus (police), there is collusion of a neat series of cooperation from top to bottom in the criminal act of embezzlement in a position so that it is difficult to find and because of the shrewdness of the accused or the embezzler in the position itself, the cleverness of the perpetrator criminal embezzlement in a position to cover up his crimes, especially with the advancement of technology today. Solutions in overcoming obstacles in the process of investigating criminal acts of embezzlement in positions within the jurisdiction of the Ciamis Police: Investigators must provide a sense of security if there are people who know of criminal acts of embezzlement in their positions in the jurisdiction of the Ciamis Police.
\end{abstract}

Keywords: Investigation; Crime; Embezzlement.

\section{Introduction}

In everyday life, humans are often faced with an urgent need, a need for complacency, sometimes even because of the desire or urge to maintain one's status. In general, human needs will be met, although not entirely, in a situation that does not require pressure from within or from others. Towards an urgent need to be fulfilled and must be met immediately, it is usually carried out without careful thought that can harm the environment or other humans. Things like that because it causes a negative result that is not balanced with a good atmosphere and life.

Law is a social rule made by certain institutions, such as the government, so that it explicitly prohibits and forces people to behave in accordance with the wishes of the regulators. Violation of this legal norm takes the form of fines to physical punishment 
(imprisonment to death). The characteristics are as follows: ${ }^{1}$

- Definite (written) rules

- Tie everyone up

- Has rule enforcement tools

- Made by rulers

- Be pushy

- The sanctions are heavy

Law is often understood by the public as a set of rules made by the State that binds its citizens to the mechanism of the existence of sanctions as an enforcer to enforce the law. The state has the right to force the imposition of sanctions for acts that violate the law where the perpetrator is found guilty by a court decision which has permanent legal force.

The law has several roles in regulating people's behavior. There are three main roles of law in society, namely as follows: ${ }^{2}$ first, as a means of social control, second as a means of smoothing the process of social interaction and third as a means of creating certain conditions.

An act which constitutes a crime or violation is defined in the laws of the Republic of Indonesia as an act that endangers a legal interest. By stipulating the prohibition of committing an act accompanied by threats or criminal sanctions for anyone who violates it or acts against the law, it means that the law has provided legal protection for these legal interests.

Based on the opinion of Sri Endah Wahyuningsih ${ }^{3}$, that law is based on Pancasila and the 1945 Constitution in accordance with the demands of development and is able to respond to the development of society both at the national and global levels. Legal development aims to accelerate and increase the activities of reforming and forming the national legal system in all its aspects, ensuring the sustainability and integrity of the nation, as well as providing benchmarks, direction and encouragement in social change towards the realization of a just and prosperous society based on Pancasila and the 1945 Constitution.

The Indonesian state is based on the law, as stated in the 1945 Constitution Article 1 paragraph (3), namely the State of Indonesia is a constitutional state, and in exercising its rights and freedoms, citizens are regulated in Article 28:

(1) Everyone is obliged to respect the human rights of others in an orderly life in society, nation and state

(2) In exercising their rights and freedoms, everyone is obliged to comply with the restrictions established by law for the sole purpose of guaranteeing recognition and respect for the rights and freedoms of others and to fulfill fair demands in accordance with considerations of moral, religious values, security and public order in a democratic society

The development of criminal acts along with the development of the times is increasingly happening. This cannot be separated from the increasingly sophisticated

\footnotetext{
${ }_{1}^{1}$ Wawan Muhwan Hariri, 2012, Pengantar Ilmu Hukum, Bandung: Pustaka Setia, p. 39

2 Teguh Prasetyo, 2011, Kriminalisasi dalam Hukum Pidana, Bandung: Nusa Media Publisher

${ }^{3}$ Sri Endah Wahyuningsih, 2013, Prinsip-Prinsip Individualisasi Pidana dalam Hukum Pidana Islam, Semarang: Diponegoro University Publishing Agency
} 
development of the era so that the mode of crime is increasingly sophisticated. This development greatly influenced various parties / individuals to do or justify any means that could result in losses in terms of wealth that would be suffered by someone who was a victim of the crime.

Various criminal acts that occur in society, one of which often occurs is the crime of embezzlement. The criminal act of embezzlement is set out in Book II of Chapter XXIV of the Criminal Code (Penal Code) entitled "Destruction". The criminal act of embezzlement is regulated in Articles Several items, namely Article 372 up to Article 377 of the Criminal Code. ${ }^{4}$

The criminal act of embezzlement in a position which is a crime that starts with a belief in another person, and that trust is lost because of a lack of honesty. Even today, there are many cases of embezzlement in positions with various modes which indicate the increasing rate of crime, especially in the Ciamis Police jurisdiction.

Embezzlement in a position which is a crime often occurs in various fields and even the perpetrators are in various levels of society. Both the lower and upper layers who commit this crime. Seeing the many cases of embezzlement in office in general that occur in Indonesia, of course this is very concerning.

Abuse of trust which dominates as an element of embezzlement in this position. The crime of embezzlement is broadly regulated in the Criminal Code, namely Article 372 of the Criminal Code concerning ordinary embezzlement, Article 373 of the Criminal Code regarding light embezzlement, Article 374 of the Criminal Code and Article 375 of the Criminal Code concerning embezzlement by weight, Article 376 of the Criminal Code regarding embezzlement in families.

The success in uncovering a criminal act depends on the investigation and investigation process carried out by the Police, especially the investigator. The pros and cons of an investigation really depend on how to handle it. A good investigation, the result of which has been tested by statutory evidence, will greatly assist in the success of the prosecution work. In the context of strengthening the position, organization and function of law enforcers in preliminary examinations, it is necessary to strengthen the relationship between the police and prosecutors in the field of investigation. The prosecutor as public prosecutor clearly needs help and tools that are strong and dexterous. It is hoped that the police with all the completeness of their investigations and investigations can expedite the task of completing criminal case submissions to the Court.

Investigation is a series of activities / actions by an investigator in matters and according to ways regulated in this law to seek and collect evidence which with this evidence sheds light on the criminal act that has occurred in order to find a suspect (Article 1 point 2 of the Criminal Procedure Code) ${ }^{5}$.

Based on the opinion of Umar Ma'ruf as outlined in the journal, that: "The number of criminal acts committed by the community, especially murder, has made the police apparatus, namely investigators, to carry out investigations and in uncovering a

\footnotetext{
${ }^{4}$ Tito Dwi Anggoro, "Implementation Enforcement Embezzlement Of Rental Vehicle Crime In Polsek Banyuurip Satker Polres Purworejo" in Jurnal Daulat Hukum Volume 1 Issue 3 September 2018, p.. 630 http://jurnal.unissula.ac.id/index.php/RH/article/view/3347

${ }^{5}$ Full KUHAP, 2004, Penerbit Bumi Aksara, p. 5
} 
criminal act, evidence is needed." From this opinion that in order to make clear the existence of a criminal act, an investigation and evidence are needed ${ }^{6}$.

Based on the above formulation, the main task of the investigator is to find and collect evidence with evidence and find the suspect ${ }^{7}$. According to research conducted by the author in the jurisdiction of the Ciamis Police with cases Police Report Number: LP / 74 / B / III / 2019 / JBR / SPKT Res Ciamis, dated 30 March 2019 on behalf of the reporter OHT Bin J A.

Where the case in that case is the criminal act of embezzlement in the position of money of approximately Rp. 499,100,000, - (four hundred and ninety-nine million and one hundred rupiah) by means of the suspect $\mathrm{Hj}$. TJ Binti $\mathrm{K}$ as dean of the health sciences faculty at Galuh Ciamis University did not make a report on the accountability of the use of the finance of the 2016/2017 Nurse Professional Program which is based on the decision letter of the board of the Galuh Ciamis education foundation Number 001 / SK / YPG-CMS / VII / 2014 in the second dictum that The allocation of funds for the professional program is $90 \%$ for Faculties, $5 \%$ for the Recto rate and $5 \%$ for foundations.

The purpose of this research to find out and analyze the process of investigating criminal acts of embezzlement in positions in the Ciamis Police jurisdiction, obstacles in the process of investigating criminal acts of embezzlement in positions in the Ciamis Police jurisdiction, and analyzing solutions in overcoming obstacles in the process of investigating criminal acts of embezzlement in positions in the region the law of the Ciamis Police.

\section{Research Methods}

Approach Method: Juridical Empirical, a way to solve research problems by examining secondary data first and then continuing research on primary data in the field. Research Specifications: descriptive analysis, focusing on the problem and then processed and analyzed to draw conclusions ${ }^{8}$.

Data collection methods, namely primary data: interviews and secondary data: relevant literature studies, either in the form of theories or opinions from experts documented in the literature ${ }^{9}$. Data Analysis Method: qualitative analysis, namely by describing data in the form of regular, logical and effective sentences ${ }^{10}$.

\section{Research Results And Discussion}

\subsection{The Process Of Investigating The Criminal Act Of Embezzlement In A Position In The Jurisdiction Of The Ciamis Police}

\footnotetext{
${ }^{6}$ Wahyu Sudrajad, Umar Ma'ruf, "Rekontruksi Sebagai Upaya Mengungkap Tindak Pidana Pembunuhan Berencana (Studi Kasus Wilayah Hukum Polsek Banyumanik Semarang)", in Journal Khaira Ummah, Vol 12. No 3

7 Leden Marpaung, 2009, Proses Penanganan Perkara Pidana (Penyelidikan dan Penyidikan), Jakarta: Sinar grafika, p.11

${ }^{8}$ Saifuddin Azwar, 2014, Metode Penelitian, Yogyakarta: Pustaka Pelajar, p. 7

9 Soerjono Soekanto dan Sri Mamudji, 1985, Penelitian Hukum Normatif, Suatu Tinjauan Singkat, Jakarta: Raja Grafindopersada, p. 66.

${ }^{10}$ Bambang Waluyo, 2002, Penelitian Hukum dalam Praktek, Jakarta: Sinar Grafika, p. 78.
} 
In the Indonesian legal system, criminal law can be interpreted in a narrow way and can be interpreted broadly. Criminal law in a narrow sense is only a material criminal law, which contains norms that govern actions which constitute a criminal act and the crime. Meanwhile, criminal law in a broad sense consists of criminal law (substantive or material) and criminal procedure law (formal criminal law) ${ }^{11}$.

Regarding criminal procedural law, it is necessary to put forward Moelijatno's opinion as follows "how to maintain the procedure for prosecuting people suspected of committing criminal acts. Therefore, this part of the criminal law is called formal criminal law (criminal procedure) ${ }^{12}$."

In general, criminal procedural law in Indonesia has been codified into one document, namely Act No. 8 of 1981 concerning Criminal Procedure Law or commonly referred to as the Criminal Procedure Code (hereinafter referred to as KUHAP).

In the Criminal Procedure Code, it has been regulated regarding the proceedings in the handling of crimes which consist of: Pra-Investigation, Investigation, Prosecution, and Examination in Court Session.

Embezzlement in a position which is a crime often occurs in various fields and even the perpetrators are in various levels of society. Both the lower and upper layers who commit this crime. Seeing the many cases of embezzlement in office in general that occur in Indonesia, of course this is very concerning. Abuse of trust which dominates as an element of embezzlement in this position. The crime of embezzlement is broadly regulated in the Criminal Code, namely Article 372 of the Criminal Code concerning ordinary embezzlement, Article 373 of the Criminal Code regarding light embezzlement, Article 374 of the Criminal Code and Article 375 of the Criminal Code concerning embezzlement by weight, Article 376 of the Criminal Code regarding embezzlement in families.

In the investigation process, the investigator after receiving a report or complaint about a criminal act, he conducts an examination at the crime scene (TKP). Based on Article 75 of the Criminal Procedure Code, the results of the examination at the TKP are made an examination report.

Investigation of suspects of embezzlement in positions in the Ciamis Police jurisdiction with the case Police Report Number: LP / 74 / B / III / 2019 / JBR / SPKT Res Ciamis, dated March 30, 2019 on behalf of the OHT Bin JA reporter, according to statutory regulations -The KUHAP legislation is carried out based on the procedures for handling criminal acts, so the following steps are taken: (a) Crime Scene Examination, (b) Investigation, (c) Preparation of Minutes, (d) Examination of evidence: Search, confiscation, (e) Expert statement, (f) The arrest or detention and examination of the suspect, (g) Resume, and (h) Submission of files.

In the context of carrying out an investigation, it is necessary to pay attention to efforts to maintain a balance between evidence, evidence of a criminal act and procedures for investigation by investigating officials. Where the evidence is regulated in Article 184 KUHAP, the evidence is as follows: Witness statement, Expert statement, Letter, Instructions, Statement of the Defendant.

\footnotetext{
${ }^{11}$ Andi Hamzah, 2005, Hukum Acara Pidana Indonesia, Jakarta: Sinar Grafika, p. 9.

${ }^{12}$ Moeljatno, 2002, Asas-Asas Hukum Pidana, Jakarta: Rineka Cipta, p. 6
} 
The balance in the investigation process is maintained in relation to the fact that investigative action can take the form of summoning, examining, searching, confiscating or detaining people, all of which are closely related to human rights.

\subsection{Obstacles In The Process Of Investigating Criminal Acts Of Embezzlement In Positions Within The Ciamis Police Jurisdiction}

According to the results of the research conducted by the author, there are several reasons that are obstacles for law enforcement officials in examining / resolving criminal acts of embezzlement in positions in the Ciamis Police jurisdiction:

- Not everyone who knows, hears of the crime of embezzlement in their position in the Ciamis Police jurisdiction is willing to report it to the legal apparatus (police).

- The collusion of a series of neat collaborations from top to bottom in the criminal act of embezzlement in a position in the Ciamis Police jurisdiction, making it difficult to find and due to the shrewdness of the accused or the embezzler in the position itself.

- The ingenuity of the perpetrators of embezzlement in positions in the Ciamis Police jurisdiction in covering up their crimes, especially with the advancement of technology today.

Not everyone who knows, hears or sees the crime of embezzlement in his position in the Ciamis Police jurisdiction is willing to report it to the police. Even though the reporters must be guaranteed their confidentiality, they are reluctant to report it.

\subsection{Solutions In Overcoming Obstacles In The Process Of Investigating Criminal Acts Of Embezzlement In Positions In The Ciamis Police Jurisdiction}

Solutions in overcoming obstacles in the process of investigating criminal acts of embezzlement in positions in the Ciamis Police jurisdiction are as follows:

- Investigators must provide a sense of security if there are people who are aware of the crime of embezzlement in their position in the Ciamis Police jurisdiction

- The public must have the courage to report to the authorities if people who know or hear or see the crime of embezzlement in their position in the Ciamis Police jurisdiction

- Increase human resources, especially investigating officers and improve the facilities and infrastructure needed to uncover a criminal act of embezzlement in a position in the Ciamis Police jurisdiction.

- The government provides education to the public regarding the law, so that if the public finds out about a criminal act, they immediately report to the authorities and the police must provide a sense of security to the reporting party.

\section{Closing}

\subsection{Conclusion}

Investigation of suspects of embezzlement in positions in the Ciamis Police jurisdiction with the case Police Report Number: LP / 74 / B / III / 2019 / JBR / SPKT Res Ciamis, 
March 30, 2019 on behalf of the OHT Bin JA reporter, according to laws and regulations -Regulation of the Criminal Procedure Code is carried out based on the procedure for handling criminal acts, then it takes the following steps: Crime Scene Investigation, Investigation, (c) Making Minutes, Examination of evidence: Search, seizure, Expert statement, Arrest or detention and examination of suspects, Resume and Submission of files. Obstacles in the process of investigating criminal acts of embezzlement in positions in the Ciamis Police jurisdiction : Not everyone who knows, has heard of a criminal act of embezzlement in a position in the Ciamis Police jurisdiction, wants to report to the legal apparatus (police), there is collusion of a neat series of cooperation from top to bottom in the crime of embezzlement in positions in the Ciamis Police jurisdiction so that It is difficult to find and because of the shrewdness of the accused or the embezzler in the position itself, the ingenuity of the embezzler in a position in the Ciamis Police jurisdiction in covering up his crimes, especially with the advancement of technology today. Solutions in overcoming obstacles in the investigation process of embezzlement in a position in the Ciamis Police jurisdiction. Investigators must provide a sense of security if there are people who know of a criminal act of embezzlement in their position in the Ciamis Police jurisdiction, the community must have the courage to report to the authorities if people who know or hear or see the occurrence of embezzlement in their position in the Ciamis Police jurisdiction, Increase human resources, especially the investigating apparatus and improve the facilities and infrastructure needed to reveal a criminal act of embezzlement in a position in the Ciamis Police jurisdiction, the government provides counseling to the public about the law, so that if the community finds out about a criminal act, they immediately report to the authorities and parties. The police must provide a sense of security to the reporting party.

\subsection{Suggestions}

For the Police : Increasing human resources, especially investigators by holding special training or courses, Improve Police facilities and infrastructure in terms of supporting investigators' duties, In imposing a sentence must be strictly in accordance with the Criminal Code, so that the deterrent effect for the perpetrator. For the Community: The public must assist the Police by reporting incidents of criminal acts, for example the existence of embezzlement in their positions in the Ciamis Police jurisdiction; The public must be willing to be a witness in revealing the crime; The community must cooperate with the police in creating a sense of security

\section{Bibliography}

Journal

Tito Dwi Anggoro, "Implementation Enforcement Embezzlement Of Rental Vehicle Crime In Polsek Banyuurip Satker Polres Purworejo" in Jurnal Daulat Hukum Volume 1 Issue 3, September 2018, p. 630 http://jurnal.unissula.ac.id/index.php/RH/article/view/3347 
Wahyu Sudrajad, Umar Ma'ruf, "Rekontruksi Sebagai Upaya Mengungkap Tindak Pidana Pembunuhan Berencana (Studi Kasus Wilayah Hukum Polsek Banyumanik Semarang)", in Journal Khaira Ummah, Vol 12. No 3.

Zaenul Arifin, Sri Endah Wahyuningsih, Sri Kusriyah, 2017, Proses Penegakan Hukum Terhadap Pelaku Tindak Pidana Penipuan Dan Atau Penggelapan Berkedok Biro Jasa Ibadah Umroh Dengan Biaya Murah (Studi Kasus Pada Penyidik Sat Reskrim Polrestabes Semarang), Khaira Ummah Journal of Law

Muhari Supa'at, 2018, Proses Penegakan Hukum Terhadap Pelaku Tindak Pidana Penggelapan Mobil Di Polres Pati (Studi Kasus Nomor BP/05/VIII/2017/Reskrim), Khaira Ummah Legal Journal

Books

Andi Hamzah, 2005, Hukum Acara Pidana Indonesia, Jakarta: Sinar Grafika

Bambang Waluyo, 2002, Penelitian Hukum dalam Praktek, Jakarta: Sinar Grafika

Leden Marpaung, 2009, Proses Penanganan Perkara Pidana (Penyelidikan dan Penyidikan), Jakarta: Sinar Grafika

Moeljatno, 2002, Asas-Asas Hukum Pidana, Jakarta: Rineka Cipta

Sri Endah Wahyuningsih, 2013, Prinsip-Prinsip Individualisasi Pidana dalam Hukum Pidana Islam, Semarang: Diponegoro University Publishing Agency

Saifuddin Azwar, 2014, Metode Penelitian, Yogyakarta: Pustaka Pelajar

Soerjono Soekanto and Sri Mamudji, 1985, Penelitian Hukum Normatif, Suatu Tinjauan Singkat, Jakarta: Raja Grafindopersada

Teguh Prasetyo, 2011, Kriminalisasi dalam Hukum Pidana, Bandung: Nusa Media Publisher

Wawan Muhwan Hariri, 2012, Pengantar Ilmu Hukum, Bandung: Pustaka Setia

Full KUHAP, 2004, Penerbit Bumi Aksara 